\title{
VALUE-MOTIVATIONAL COMPONENT OF A HEALTHY LIFESTYLE OF MODERN UNIVERSITY STUDENTS: THE REAL STATE AND LOGIC OF FORMATION
}

DOI: 10.36740/WLek202105106

\author{
Dmytro V. Zhelanov ${ }^{1}$, Borys I. Palamar², Tetiana S. Gruzieva² ${ }^{2}$ Victorija V. Zhelanova ${ }^{3}$, Inna V. Leontieva ${ }^{3}$, \\ Maryna A. Yepikhina ${ }^{4}$ \\ ${ }^{1} G$. S. SKOVORODA KHARKIV NATIONAL PEDAGOGICAL UNIVERSITY, KHARKIV, UKRAINE \\ ${ }^{2}$ BOGOMOLETS NATIONAL MEDICAL UNIVERSITY, DEPARTMENT OF SOCIAL MEDICINE AND PUBLIC HEALTH, KYIV, UKRAINE \\ ${ }^{3}$ PEDAGOGICAL INSTITUTE, BORYS GRINCHENKO KYIV UNIVERSITY, KYIV, UKRAINE \\ ${ }^{4}$ PEDAGOGICAL INSTITUTE, LUGANSK NATIONAL TARAS SHEVCHENKO UNIVERSITY, STAROBILSK, UKRAINE
}

\begin{abstract}
The aim: The article presents the theoretical substantiation of the value-motivational component of a healthy lifestyle, the diagnostic procedure, the results of quantitative and qualitative analysis of the real state of its formation in students of modern universities; the pedagogical tools of health-oriented, containing interactive and reflexively oriented forms and methods of educating a healthy lifestyle are presented; specific examples of their implementation are given.

Materials and methods: A set of general scientific methods (analysis, synthesis, comparison, systematization, generalization) and diagnostic standardized methods (M. Rokich's "Value orientations" method, R. Berezivska's questionnaire "Attitude to health" (value-motivational scale), questionnaire"Motivational component of a healthy lifestyle" (N. Voloshko, V. Rybalka).

Results: A healthy lifestyle is a way of life based on the value attitude to maintaining, improving and strengthening health through motivated activities aimed at improving living conditions, which ensures quality self-realization of the individual in all spheres of life. An essential component of the structure of a healthy lifestyle is the value-motivational component as a set of motives, needs, attitudes to maintain one's own health and fostering a sense of responsibility for it. The pedagogical tools of health orientation are a set of interactive and reflexively oriented forms and methods of forming a healthy lifestyle, which are based on the partner subject-subject interaction of teacher and students, their dialogue, polylogy and cooperation.

Conclusions: Theoretical understanding and the results of diagnostic research made it possible to determine the nature and structure of a healthy lifestyle, to determine the real state of formation of its value-motivational component and to develop pedagogical tools of health orientation.
\end{abstract}

KEY WORDS: health, healthy lifestyle, value-motivational component of healthy lifestyle, pedagogical tools of health orientation

Wiad Lek. 2021;74(5):1079-1085

\section{INTRODUCTION}

The urgency of the problem of a healthy lifestyle is due to the strategy of the state to preserve and strengthen the health of the nation as the main priority of modern Ukrainian society. However, with the development of computer, information and communication technologies, physical activity decreases, the priority of a healthy lifestyle is lost, and modern youth is indifferent to their own health, which hinders their full and harmonious development. Therefore, the problem of students' values of health, which accumulates in a healthy lifestyle, becomes especially relevant.

The new paradigm of health was thoroughly defined by Academician M. Amosov. The statement of a famous doctor-scientist, which sounds as follows: "To become healthy, your own efforts have to be applied, constant and significant. There is nothing to replace them" [1], has already become an aphorism and a guide in the healthy life of many modern people. It is obvious that this position is based on the axiological aspects of a healthy lifestyle that are related to the value attitude towards health; motives, needs to lead a healthy lifestyle; attitudes to the rules and norms of a healthy lifestyle.

\section{THE AIM}

Analyze the value-motivational component of a healthy lifestyle and diagnose the real state of its formation on a representative sample of masters of higher education, as well as justify the logic of forming a healthy lifestyle in students of modern universities.

The hypothesis of the study is that the pedagogical tools of health orientation should include interactive forms and methods of forming a healthy lifestyle, which are based on the partner subject-subject interaction of the teacher and students. 


\section{MATERIALS AND METHODS}

A set of general scientific methods (analysis, synthesis, comparison, systematization, generalization) and diagnostic standardized methods (M. Rokich's "Value orientations" method, R. Berezivska's questionnaire "Attitude to health" (value-motivational scale), questionnaire "Motivational component of a healthy lifestyle” (N. Voloshko, V. Rybalka) are used in the work.

\section{RESULTS AND DISCUSSION}

Let's define certain initial positions of our research. Modern science offers more than 200 definitions of "human health" [2]. Our interpretation of the phenomenon of health is based on the understanding of health as a set of somatic health, which is the biological program of individual development and is the state of the organs and systems of the human body; physical health as a level of growth and development of organs and systems of the body that provide adaptive responses; mental health as a state of the mental sphere that provides an adequate behavioral response; mental health as a set of characteristics of the value-motivational sphere of life, based on the system of values, attitudes and motives of individual behavior in society [3]; psycho-emotional health as a state of the mental sphere, the presence or absence of neuropsychiatric diseases, the ability to understand and express one's feelings, control emotions, ways of expressing attitudes towards oneself and people; intellectual aspect of health, which involves the quality of assimilation of information, its use, the effectiveness of search and accumulation of the necessary information, which ensures the development of personality and its adaptation to the environment; the social aspect of health is related to the individual's awareness of himself as a subject of interaction with others, the way of communication and attitude to different groups of people; the personal aspect of health reflects self-awareness, development of one's own "I", self-feeling, harmonious combination of different ways and goals of self-realization [4, p. 35 - 36].

In the context of our study, it is advisable to axiologically interpret the essence of health as a person's own value, which allows one to fully express oneself through a stable biological, social, psychological state in any activity (educational, professional, sports, etc.) $[5,6,7]$. Thus, modern interpretations of the phenomenon of health are based on the integration of its axiological, social, spiritual, physical and mental components that determine the holistic well-being of a man. At the same time, we consider O. Savchenko's conclusion that the most complete relationship between lifestyle and health is reflected in the concept of "Healthy lifestyle" [8, p. 10].

Taking into account the above-mentioned points of view, the definition of health as an interaction of biological and social factors, as well as the conclusion that human health is not reduced to a certain physical condition, but involves psycho-emotional balance, spiritual and social health, there is an obvious need to reorient people from the treatment of diseases to care for their health, to understand the fact that the main cause of ill health - a person's indifference to himself. According to N. Romanova, the improvement of health is associated primarily with the conscious, intelligent work of man himself to strengthen, restore and develop the vital resources of the body [9].

Therefore, we believe that an essential component of the structure of a healthy lifestyle is the value-motivational component as a set of motives, needs, attitudes to maintain one's own health and fostering a sense of responsibility for it. Going through the realm of emotions, motives become the need to follow the rules of a healthy lifestyle. Taking into account the position of D. Uznadze [10], by setting a healthy lifestyle we understand the state of a person's propensity to act in a given unambiguous way, the orientation of his consciousness to a functionally defined activity. Therefore, the value attitude towards health is a stable positive attitude; tendency to maintain and promote health; personal interest.

Thus, in the value-motivational component of a healthy lifestyle, the motivating, directing, regulatory, corrective, meaning-forming functions of motives, needs and values are realized.

Taking into account the above-mentioned theoretical positions, we note that our experimental study focused on diagnosing the value-motivational component of a healthy lifestyle.

The experimental study involved 94 applicants for the second (master's) level of higher education in the specialties 011 Educational, pedagogical sciences (educational and professional program 011.00.01 "Higher school pedagogy"), 012 Preschool education and 013 Primary education of the Pedagogical Institute of Borys Grinchenko Kyiv University.

In order to diagnose the formation of values of health, as well as motivation for a healthy lifestyle, we used the following methods: M. Rokich's "Value orientations" method [11], R. Berezivska's questionnaire "Attitude to health" (value-motivational scale) [12], questionnaire "Motivational component of a healthy lifestyle" (N. Voloshko, V. Rybalka methodology) [13]. As part of this method of diagnosis, respondents are presented with two lists of values (18 in each), which they must rank. Firstly, a set of terminal and then instrumental values are proposed.

For the purpose of correct statistical processing of the received results of research, the following procedure was carried out. The rank number assigned to one or another value changed to the opposite value, i.e. the first rank was assigned the value 18 , the second 17 , the third 16 , etc. By finding the average value for each of the terminal and instrumental values, throughout the sample, we found a rating of values. The data are presented in a form that involves statistical analysis. The rating of terminal values of applicants for the second (master's) level of higher education is presented in Fig. 1.

The analysis of the indicators presented in Fig. 1 gives the grounds to conclude that the following values are of the greatest importance for the respondents:

- in the first place respondents put "active life" (Wfr. = 14.7), "friends" (Wfr. = 13.5), "health" (Wfr. = 13.3), "development" (Wfr. = 12.4) and "love" (Wfr. = 11.6). 

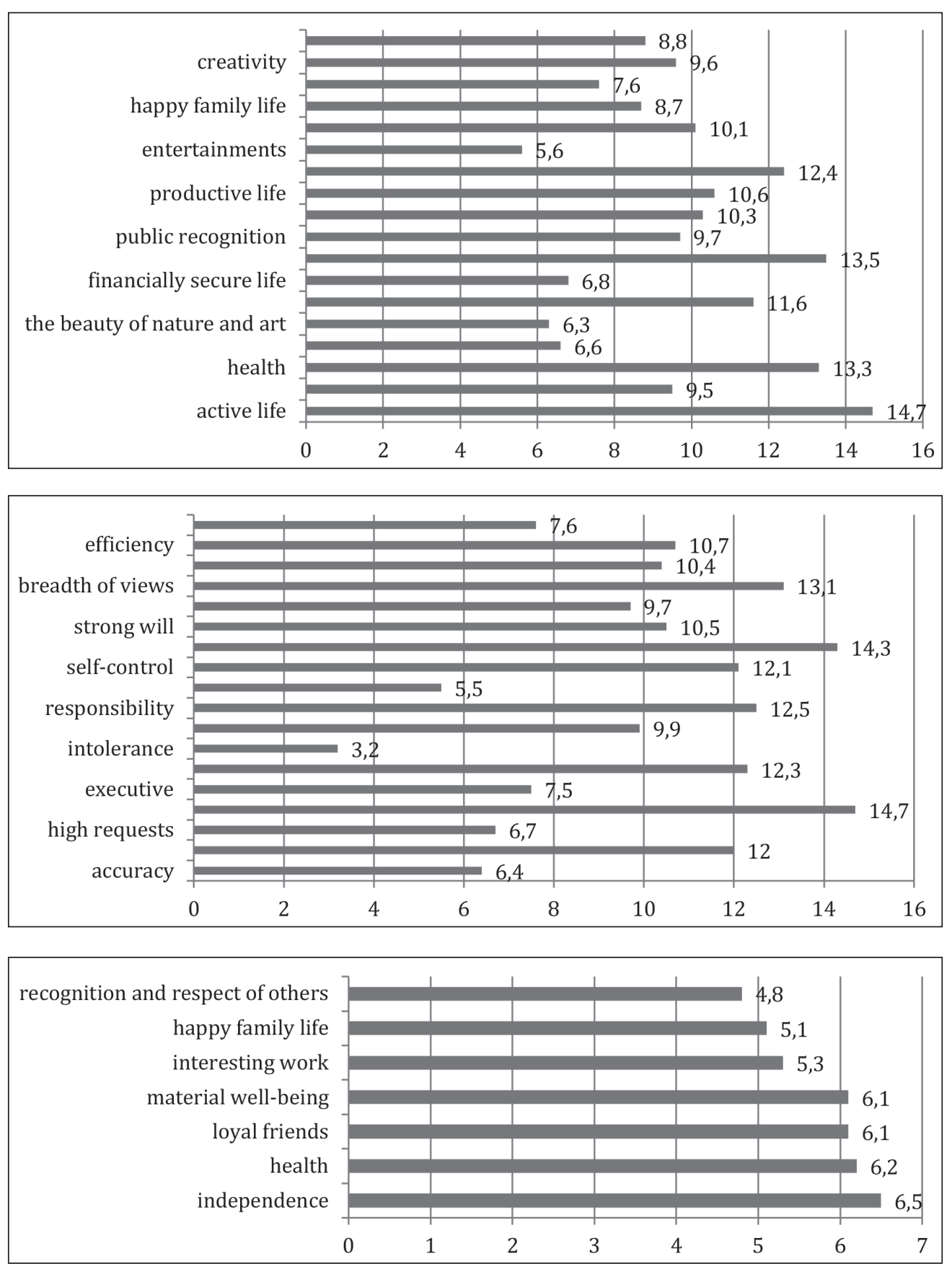

Fig. 1. Linear histogram of the rating of terminal values of Master's students

Fig. 2. Graph of the rating of instrumental values of Master's students

Fig. 3. Linear histogram of the results of assessing the significance of values at the current time
- in the last place in the rank of applicants for the second (master's level) of higher education put the following terminal values: "entertainment" $(\mathrm{Wfr} .=5.6)$, "beauty of nature" (Wfr. = 6.3) and "work" (Wfr. = 6.6).

The rating of instrumental values of respondents is presented in Fig.2. Taking into account the results of data analysis, we must state that for the surveyed respondents the rating of instrumental values is as follows:

- the most important for undergraduates are such values as: "cheerfulness (sense of humor)" (Wfr. = 14.7); "courage in defending one's point of view" (Wfr. = 14.3); "breadth of views" (Wfr. =13,1); "responsibility" (Wfr. =12.5); "independence (ability to act independently, decisively)" (Wfr. =12,3). - the least significant for the respondents are the following values: "intransigence to shortcomings in oneself and others" (Wfr. = 3.2), "rationalism" (Wfr. = 5.5); "accuracy" (Wfr. $=6,4)$.

Thus, it is obvious that "responsibility", as a value, ranks fourth place in the overall ranking of instrumental values of master's students; "Firm will", namely "the ability to insist on one's own and not give in to difficulties", ranks ninth place; self-control, which is manifested in restraint and self-discipline is on the sixth place. Among the terminal values, development, which is characterized in terms of self-improvement, constant physical and spiritual improvement is on the fourth place, the value of health - one the third one. That is, values such as health and development are at the core of a person's values.

In order to study the levels of formation of a healthy lifestyle by value-motivational component, we used a 


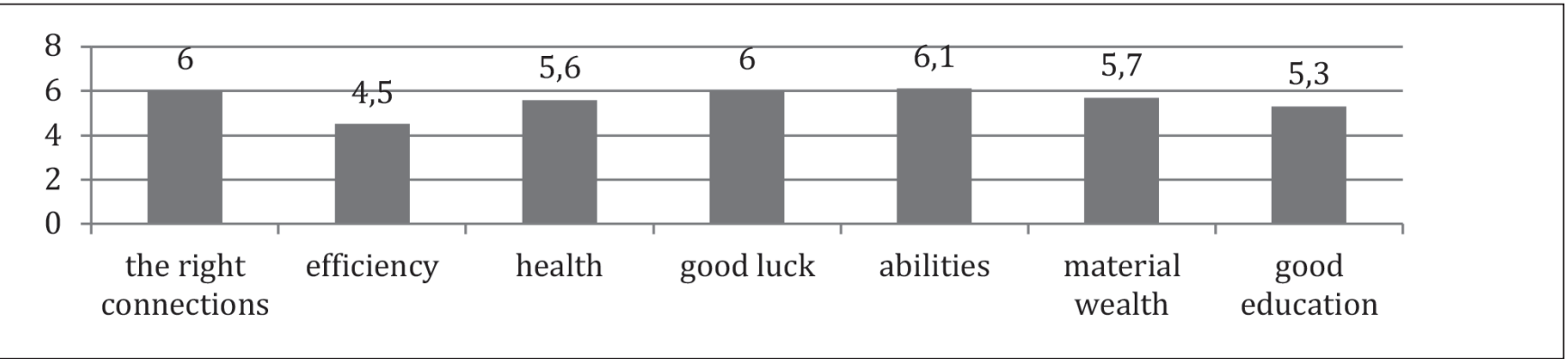

Fig. 4. A linear histogram to assess the factors that influence success in life

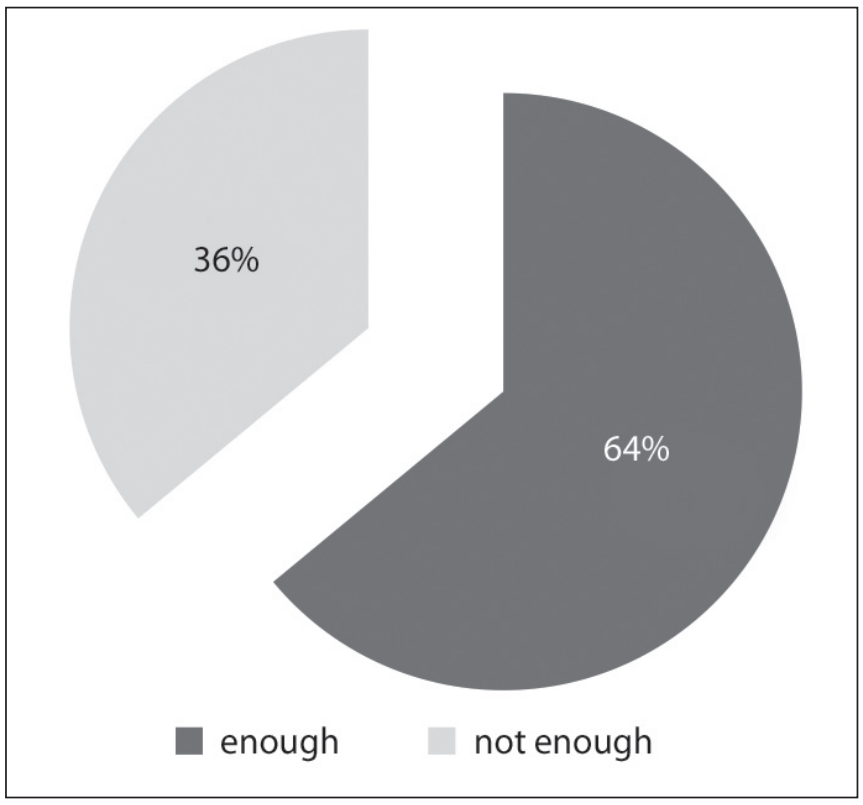

Fig. 5. Diagram of the ratio of health care indicators

motivational-value scale, which stands out in the interpretation of the results obtained by the R. Berezivska's questionnaire "Attitude to health". The purpose of this questionnaire is to determine the attitude of respondents to health. The analysis of the results was performed on the basis of qualitative analysis of the data obtained with the help of the questionnaire.

Taking into account the data shown in Fig. 3, we must state that among the respondents the first place is occupied by the value of "independence" (Wfr. = 6,5); on the second place is "health" (Wfr. =6.2); on the third - "faithful friends" (Wfr. $=6,1)$ and "material well-being" (Wfr. $=6,1)$; fourth place - "interesting work" (Wfr. = 5.3); and on the last place in the system of values of master's students "happy family life" (Wfr. = 5.1) and "recognition and respect of others" (Wfr. $=4.8$ ) were found.

Analysis of respondents' answers to the questionnaire "What do you think is necessary to succeed in life?", shown in Fig.4, gives the grounds to draw the following conclusions: according to undergraduates, to succeed in life, first of all, the individual abilities (Wfr. = 6.1); luck (temperament) (Wfr. $=6$ ); connections (support of friends, acquaintances) (Wfr. $=6$ ) are necessary. Given these results, we can assume that for applicants for the second (master's) level of higher education, external motivation and support play an important role in life. Health (Wfr. $=5.6)$, according to the respondents, is an important factor for success in life, which thus leads to the formation of motivation to maintain and strengthen health.

The results of the analysis of the answers to the question "If you care about your health insufficiently or irregularly, then why?" presented in Fig.5 and Fig.6.

Thus, the data shown in Fig. 5 show that $36 \%(n=34)$ of undergraduates take care of their health insufficiently or irregularly and $64 \%(n=60)$ devote enough time to health and do not look for reasons for non-performance of physical exercises, non-compliance with the regime, improper nutrition, etc.

At the same time, Figure 6 shows the reasons that, according to the respondents, prevent them from taking care of their own health. Thus, here are the reasons for abandoning a healthy lifestyle which are often called by master's students - "there are more important things" (Wfr. = 6.0), "I do not have time for this" (Wfr. = 5.7), "lack of willpower" (Wfr. = 5.6), "no company" (Wfr. = 5.5), "requires large material costs" (Wfr. = 5.4). That is, one can see a transfer of responsibility to external factors.

Quantitative analysis of the formation of motivation for a healthy lifestyle was conducted using the questionnaire "Motivational component of a healthy lifestyle" (N. Voloshko, V. Rybalka methodology), the results of which are shown in Table 1.

The purpose of the method is to determine the level of formation of the motivational component of a healthy lifestyle of participants in the educational process. During the work, respondents were asked to rate from -5 to 5 points the level of intensity of needs, desires and aspirations in various aspects of health (spiritual, psychological/mental, social and physical), where (-5 - the minimum score (no, strongly disagree), 5 - maximum score (yes, I absolutely agree)).

The analysis of the obtained results makes it possible to draw the following conclusions:

- in the spiritual aspect of health $32 \%(n=30)$ of undergraduates have an average-low level of motivation; $31 \%$ $(\mathrm{n}=29)$ - average level; 19\% $(\mathrm{n}=18)$ have am average-high level, $6 \%(n=6)$ have a low level of motivation for a healthy lifestyle in this aspect and vice versa $12 \%$ $(\mathrm{n}=11)$ have a high level.

- in the social aspect in 35\% ( $n=33)$ of respondents the formation of motivation is at an average level; in $21 \%$ 

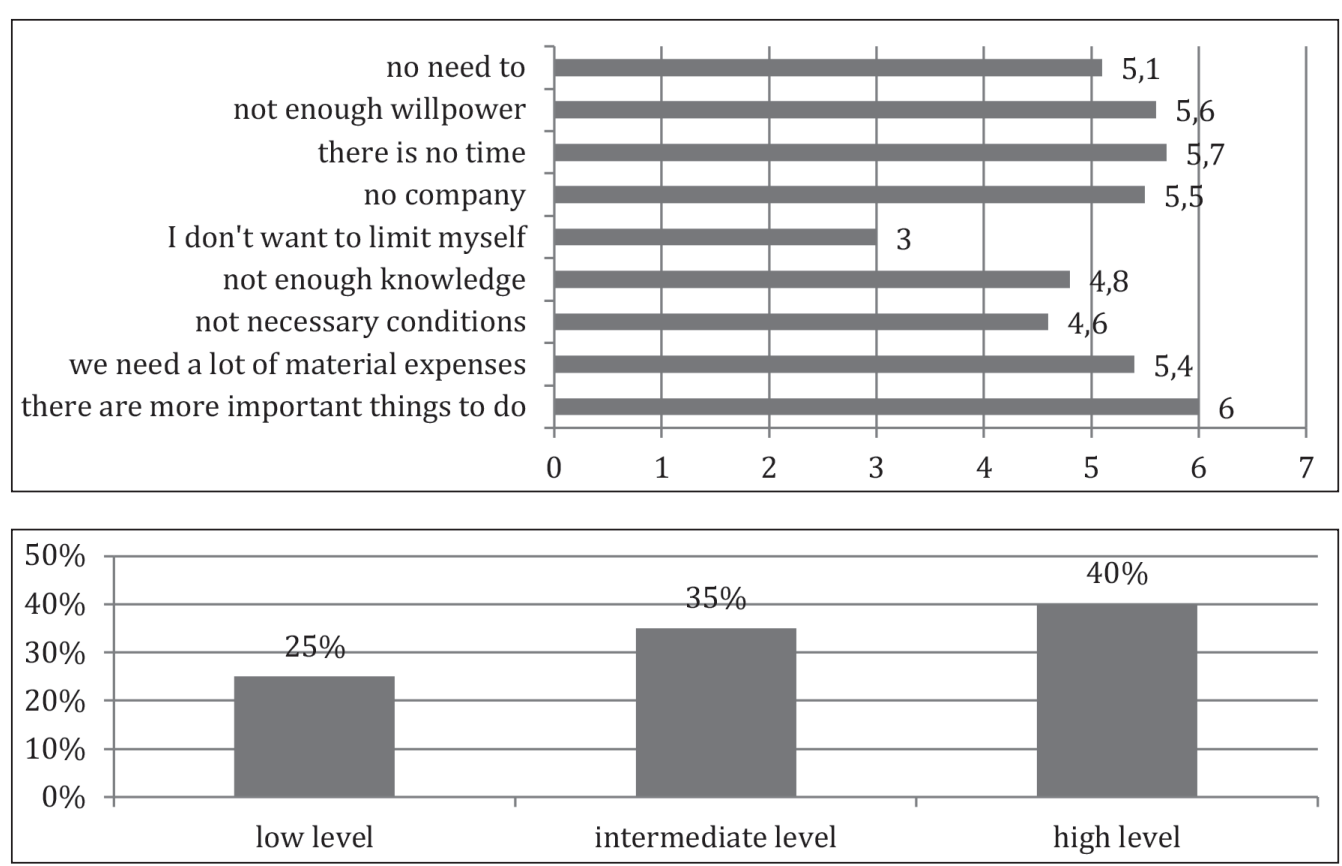

Fig. 6. Linear histogram of the causes of insufficient and irregular health care

Fig.7. Histogram of levels of motivation for a healthy lifestyle

Table I. Levels of motivation for a healthy lifestyle in different areas of health

\begin{tabular}{ccccc}
\hline Indicators & Spiritual health & Social health & Psychological health & Physical health \\
\hline Low level & $6 \%$ & $6 \%$ & $3 \%$ & $6 \%$ \\
\hline Average-low level & $32 \%$ & $13 \%$ & $23 \%$ & $12 \%$ \\
\hline Average level & $31 \%$ & $35 \%$ & $37 \%$ & $37 \%$ \\
\hline Average-high level & $19 \%$ & $21 \%$ & $25 \%$ & $31 \%$ \\
\hline High level & $12 \%$ & $25 \%$ & $12 \%$ & $14 \%$ \\
\hline
\end{tabular}

$(\mathrm{n}=20)$ - at average- high level; 13\% $(\mathrm{n}=12)$ respondents have an average-low level of formation; high level is observed in $25 \%(\mathrm{n}=23)$; low in $6 \%(\mathrm{n}=6)$.

- in the mental aspect, motivation for a healthy lifestyle, a high level is observed in $12 \%(\mathrm{n}=11)$; average-high in $25 \%(\mathrm{n}=23)$; average in $37 \%(\mathrm{n}=35)$; average-low in $23 \%(n=22)$; low level in $3 \%(n=3)$ of undergraduates. - in the physical aspect $37 \%(\mathrm{n}=35)$ of respondents have an average level of motivation for a healthy lifestyle; $31 \%$ $(\mathrm{n}=29)$ - average-high level; $12 \%(\mathrm{n}=11)$ - average-low; $14 \%(n=13)$ have a high level of motivation; $6 \%(n=6)$ have a low level of motivation in the physical aspect.

In Fig. 7 one graphically presents the general level of motivation for a healthy lifestyle among undergraduates. A high level includes average-high levels, and a low level includes average-low levels.

The analysis of the obtained data gives grounds to conclude that in general, i.e. in the context of all four components of health, the formation of motivation for a healthy lifestyle in respondents is as follows: a high level is observed in $40 \%(\mathrm{n}=38)$; average in $35 \%(\mathrm{n}=33)$ and low in $25 \%(\mathrm{n}=23)$ of applicants of the second (master's) level of higher education.

Thus, based on the analysis of the characteristics of respondents' values of health, we can conclude on the importance of health and development in the hierarchy of values. Among the terminal values, health ranks $3^{\text {rd }}$ and development ranks $4^{\text {th }}$ place in the overall sample. Based on the obtained data, we can conclude that such values as health and development in the hierarchy of values of respondents occupy a fairly high priority, and are part of the motivational core.

Sufficient level of motivation to maintain and strengthen health, which is manifested in the understanding of the importance of health for success and awareness of the need to take care of one's health, however at this stage the motivation is not internal but depends on external facts (parents, friends, conditions, finances, etc.). Health values are at the forefront of the personality hierarchy. It should be noted that the level of motivation for a visual lifestyle is more pronounced in the physical and social aspects of health, in the spiritual aspect - the average-low level of motivation for a healthy lifestyle prevails. The need for a healthy lifestyle is quite stable, but is mostly external.

Taking into account the results of quantitative and qualitative analysis of the real state of formation of a healthy lifestyle, the pedagogical tools of health orientation based on interactive forms and methods of forming a healthy lifestyle which are grounded on the partner subject-subject interaction of the teacher and students, on their dialogue, polylogue and cooperation, were substantiated and developed. 
In our opinion, the appropriate interactive method of forming a healthy lifestyle is the method of analysis of specific situations or case-study. Case is a description of a real life situation, containing accompanying facts, opinions, judgments, which are based on solving a problem. The case is always based on a contradictory situation that has actually occurred or may arise. So the essence of this method is that the information is presented in the form of a problem, and knowledge is acquired in the process of analytical activities. This method is effective in forming a valued attitude to health, the ability to analyze your lifestyle; to form one's own position on certain events of other people's way of life.

In the process of experimental work, the method of situation analysis was used on the material of real confessions of drug addicts [14] in order to cultivate drug resistance as a psychological basis for preventing bad habits and forming an attitude to a healthy lifestyle. In working with situations-confessions it is possible to use the following algorithm: 1. Familiarity with the situation and its perception. 2. Interpretation and understanding of the situation in the following aspects: at what age, as well as for what reasons the first acquaintance with drugs took place; how drug addiction developed and how it manifested; analysis of the consequences of drug addiction; whether it is possible to defeat drugs and in what way. 3. Formation of attitude to the situation. 4. Representation of one's version of the solution of the problem.

An appropriate interactive method of forming a healthy lifestyle for students of a modern university is "brainstorming". Its essence is to formulate as many ideas as possible related to the problem, which is discussed and carried out in two stages: 1. Formulation of certain hypotheses $(5-10$ minutes, during which participants express their opinions, which are recorded without comments and assessments). 2 . Evaluation of ideas (10 - 15 minutes). At this stage, similar ideas are classified, discussed and evaluated, unproductive ideas are deleted from the general list.

Here is an example of using the method of brainstorming in the formation of motives and needs of rational eating behavior, which is a set of forms of human behavior, including mode (frequency, distribution over time), pace (speed) of food intake, predominant consumption of certain foods, motives and reasons to food intake, subjective attitude to the process of nutrition [15]. We have proposed and tested brainstorming "The impact of eating behavior on social, mental and physical health". The content of the brainstorming was to discuss a number of issues according to the method of I. Malkina-Pykh [16], among which are the following questions:

1. How and when is our eating behavior formed?

2. Why can it be disturbed?

3. What are the types of eating disorders that lead to overweight?

4. How to recognize in the body a feeling of hunger, and how - appetite?

5 . How is the ideal body weight calculated?

6 . What is obesity?
7. How is eating behavior regulated?

8. How does medicine explain the occurrence of excess weight?

9. What is the nutrition strategy of a slender person?

10 . What is your diet stereotype?

Thus, the above interactive methods of forming a healthy lifestyle have significant potential for the formation of axiological aspects of a healthy lifestyle, personal subject position, critical thinking, skills of interaction, cooperation, partnership.

An essential component of the pedagogical tools of health orientation are the methods of reflexively oriented on self-knowledge and self-awareness. Since important aspects of a healthy lifestyle are the reflection of health, self-regulation of behavior, adequate self-assessment of health as the ability to self-control and self-correction, based on the mechanism of reflection. In the process of formative work we used methods of self-knowledge of reflexive orientation, developed in the study of V. Zhelanova [17]:

"My portrait in the rays of the sun"

Task content: Write your name in the center of the solar circle or draw (paste) your portrait. Then write along the rays all your qualities that are associated with the implementation or violation of a healthy lifestyle. Try to have as many rays as possible.

"What am I"

Task content: Write in two columns your characteristic qualities. In the first column - the qualities that will contribute, in your opinion, the implementation of a healthy lifestyle. In the second column - the qualities that may hinder it.

An alternative to the previous task may be to write an essay "What would I like to change in my lifestyle?".

A similar alternative may be a method of creating an attractive image of a healthy person and an ideal image of oneself (imaginary, schematic, graphic, computer).

The purpose of scientific intelligence was realized. The results of the diagnosis showed that $36 \%(n=34)$ of undergraduates take care of their health insufficiently or irregularly. This objective circumstance necessitates the further search for new tools for the formation of values to a healthy lifestyle, motivation to improve it, a stable attitude to the implementation of the canons of a healthy lifestyle. The outlined problem acquires special weight in the conditions of distribution in our society of such negative phenomena, as a passive way of life, mass obesity, smoking, alcoholism and drug addiction.

\section{CONCLUSIONS}

Theoretical understanding and the results of the diagnostic study of the value-motivational component of a healthy lifestyle (according to the following methods: M. Rokich's "Value orientations" method, R. Berezivska's questionnaire "Attitude to health" (value-motivational scale), questionnaire "Motivational component of a healthy lifestyle" (N. Voloshko, V. Rybalka), which was attended by 94 applicants for the second (master's) level of higher education in the specialties 
011 Educational, pedagogical sciences (educational and professional program 011.00.01 "Higher school pedagogy"), 012 Preschool education and 013 Primary education of the Pedagogical Institute of Borys Grinchenko Kyiv University, proved the relevance, feasibility and necessity of clarifying the real state of formation of value components of a healthy lifestyle of university students and development of pedagogical tools for health, containing interactive forms and methods of healthy lifestyle, as well as reflexive exercises with orientations that stimulate the development of self-esteem and self-regulation of a healthy lifestyle.

The aspect of the problem related to the diagnosis of the real state of formation of cognitive and activity components of a healthy lifestyle of university students and to the improvement of pedagogical tools of health orientation needs further development.

\section{REFERENCES}

1. Amosov N.M. Encyklopedia zdoroviya. Algoritm zdoroviya [Amosov's Encyclopedia. Health algorithm]. Donetsk. Stalker. 2002; 590. (in Ukrainian).

2. Bulych E.G. Valeologiya. Teorytychni osnovy valeologii [Valeology. Theoretical foundations of valeology]: textbook for students of pedagogical educational institutions of postgraduate education. Institute of Content and Teaching Methods. Kyiv. IZMH; 1997, 224. (in Ukrainian).

3. Potashnyuk R.Z. Psyhogigiena [Psychohygiene]: Textbook. Manual. Volyn. state Univ. of L. Ukrainka. Lutsk. Nadstrya. 2000; 62. (in Ukrainian).

4. YakimenkoS.I., OksenchukN.V. Formyvannya kultury zdorovogo sposoby zhyttya ychniv osnovnoi shkoly y pozaklasniy roboti. Navchalnometodychnyi posibnyk [Formation of a culture of healthy lifestyle of primary school students in extracurricular activities. Educational and methodical manual]. Kyiv. Slovo Publishing House; 2012, 288. (in Ukrainian).

5. Bashavets N.A. Teoretyko-motodologichni zasady formyvannya kultury zdorovyazberezhennya yak svitoglyadnoi orientacii studentiv vyschyh ekotomichnyh navchalnych zakladiv [Theoretical and methodological principles of forming a culture of health care as a worldview orientation of students of higher economic educational institutions]: author's dissertation of a candidate of Pedagogical Science: special. 13.00.04 "Theory and methods of professional education". Cherkasy. 2012; 40.

6. Palamar B.I., Vaskivska H.O., Palamar S.P. Didacticaspects of cognition of human as a bio-psycho-socio-cultural personality. Wiadomości Lekarskie. 2017; 70(5): 959-963.

7. Gruzieva T.S., Galiienko L.I., Pelo I. M. et al. Health and lifestyle of students' youth: status, problems and ways of solution. Wiadomości Lekarskie. 2018; 71 (9): 1753-1758.

8. Savchenko 0.Ya. Yakist I variatyvnist shkilnykh pidrychnukiv yak ymova zaprovadzhennya derzhavnykh standartiv pochatkovoi osvity [Quality and variability of school textbooks as a condition for the introduction of state standards of primary education]. Primary school. 2001;8:10 - 12 .

9. Romanova N.F. Formyvannya zdorovogo sposoby zhyttya yak sychasna strategiya protydii socialno nebezpechnym hvorobam sered ditei ta molodi: monographiya [Formation of a healthy lifestyle as a modern strategy to combat socially dangerous diseases among children and youth: a monograph]. Counteracting socially dangerous diseases: the study of Ukrainian experience. Kyiv. Pylsary; 2010, 39 - 48.
10. Uznadze D. Mindset Psychology. St. Petersburg; 2001, 414.

11. Rokeach M. The nature of human values. N.Y. Free Press; 1973, 854.

12. Berezovskaya R.A. Attitude to health. Health psychology. St. Petersburg. 2003;100-110.

13. Voloshko N.I. Psyhologiya stanovlennya zdorovogo sposoby shyttya v navchalno-vychovnomy procesi [Psychology of formation of a healthy way of life in educational process]: program-practicum: [scientific method. textbook] Kyiv. Scientific world. $2012 ; 99$.

14. Baymukhametov S. Zolotye sny; ispovedi narkomanov [Golden dreams: confessions of drug addicts]. booksonline.com.ua/review. php?book=116659. (in Russian).

15. Vakhmistrov A.V. Naryshenie pischevogo povedeniya pri cerebralnom ozhyrenii [Eating disorders in cerebral obesity]: Abstract of dissertation of candidate of Medical Studies. StP. 2006; 24.

16. Malkina-Pykh I. G. Lychniy ves. Osvoboditsya i zabyt'. Navsegda [Overweight. Free yourself and forget. Forever]. Moscow. Eksmo. 2012; 252. (in Russian).

17. Zhelanova V.V. Teoriya technologiya conteksnogo navchannya maibutnyogo vchytelya pochatkovych klasiv [Theory and technology of contextual education of the future primary school teacher]: monograph. Luhansk. Taras Shevchenko Lviv.

\section{ORCID and contributionship:}

Dmytro V. Zhelanov: 0000-0002-9017-6960 A, B,D

Borys I. Palamar: 0000-0003-2510-0713 A, B, C, D, E, F

Tetiana S. Gruzieva: 0000-0001-9254-7561 A, B, C, D, E, F

Victorija V. Zhelanova : 0000-0001-9467-1080 A, B,D

Inna V. Leontieva: 0000-0002-8084-1912 ${ }^{A, B, D}$

Maryna A. Yepikhina: 0000-0003-0199-8186 A, B,D

\section{Conflict of interest:}

The Authors declare no conflict of interest

\section{CORRESPONDING AUTHOR \\ Borys I. Palamar \\ Bogomolets National Medical University, 13 Taras Shevchenko Blvd., 01601 Kyiv, Ukraine \\ tel: +380672387654 \\ e-mail:palamar.bi@ukr.net}

Received: 19.12 .2020

Accepted: 30.03 .2021

A - Work concept and design, B - Data collection and analysis, C - Responsibility for statistical analysis, D-Writing the article, E-Critical review, $\mathbf{F}$ - Final approval of the article 